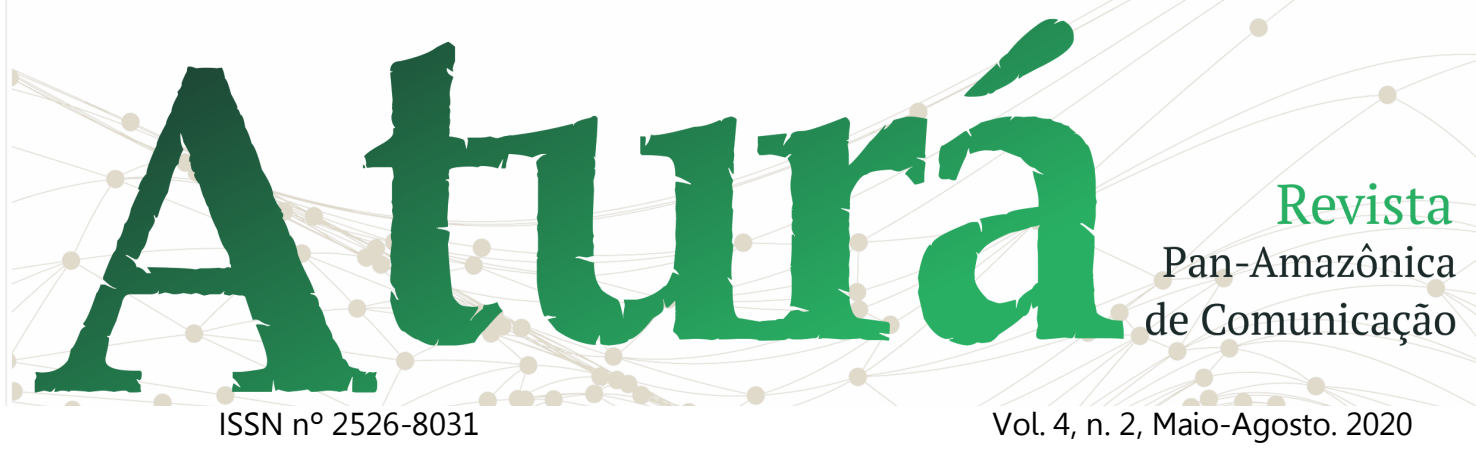

DOI: http://dx.doi.org/10.20873/uft.2526-8031.2020v4n2p59

\title{
RELIGIOSIDADE EM TEMPOS DE PANDEMIA: relato de mudanças na prática da fé católica em uma comunidade do interior da amazônia
}

Religiosity in pandemic times: report of changes in the practice of the catholic faith in a community in the interior of the Amazon

Religiosidad en tiempos pandémicos: informe de cambios en la práctica de la fe católica en una comunidad en el interior de la Amazonía

\section{Cadidja Medeiros Barros da Cunha, Universidade Federal de Rondônia ${ }^{1}$ Sandro Adalberto Colferai, Universidade Federal de Rondônia²}

\section{RESUMO}

Este artigo se propõe a realizar um relato de experiências acerca das mudanças nas estratégias comunicacionais adotada pela paróquia São João Batista de Presidente Médici, no interior de Rondônia, ocorridas após a pandemia do novo coronavírus. Para tanto, acionamos o conceito de midiatização aplicado à religião, discutido por Martino (2016) bem como a relação entre Igreja Católica e Comunicação apresentada por Puntel (2011). A fim de promover um comparativo das mudanças ocorridas utilizaremos o estudo de Cunha (2017) a respeito das estratégias midiáticas que eram acionadas pela paróquia em 2017 para então fazer as aproximações necessárias com o contexto de isolamento social imposto pela pandemia de Covid-19 no primeiro semestre de 2020. Ao cabo, não se pretende responder qual quer questionamento a respeito, mas apresentar o cenário vivenciado nesta comunidade e, a partir deles, indicar questões e trajetórias possíveis para investigação.

PALAVRAS-CHAVE: Comunicação; Amazônia; religiosidade; estratégias midiáticas; isolamento social.

\footnotetext{
${ }^{1}$ Bacharel em Jornalismo; membro do Grupo de Pesquisa em Espaços e Temporalidades Comunicacionais, COMtatos (UNIR/CNPq).

2 Doutor em Sociedade e Cultura na Amazônia; mestre em Comunicação Social; professor de Jornalismo (UNIR); líder do Grupo de Pesquisa em Espaços e Temporalidades Comunicacionais, COMtatos (UNIR/CNPq).
} 


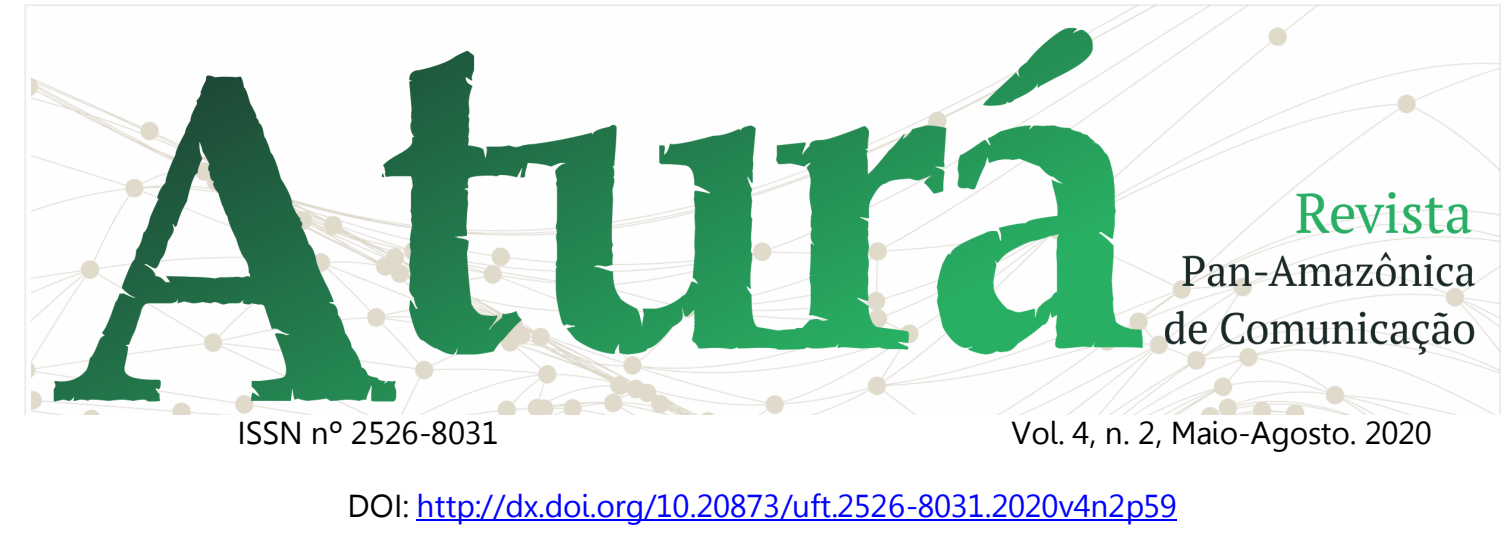

\begin{abstract}
This article proposes to carry out an account of experiences about the changes in communication strategies adopted by the parish of São João Batista de Presidente Médici, in the interior of Rondônia, which occurred after the pandemic of the new coronavirus. For that, we activated the concept of mediatization applied to religion, discussed by Martino (2016) as well as the relationship between Catholic Church and Communication presented by Puntel (2011). In order to promote a comparison of the changes that occurred, we will use the study by Cunha (2017) regarding the media strategies that were activated by the parish in 2017 to then make the necessary approximations with the context of social isolation imposed by the Covid-19 pandemic in the first semester of 2020. After all, it is not intended to answer any question about it, but to present the scenario experienced in this community and, from them, indicate possible questions and trajectories for investigation.
\end{abstract}

KEYWORDS: Communication; Amazon; religiosity; media strategies; social isolation.

\title{
RESUMEN
}

Este artículo propone llevar a cabo un recuento de experiencias sobre los cambios en las estrategias de comunicación adoptadas por la parroquia de São João Batista de Presidente Médici, en el interior de Rondônia, que ocurrieron después de la pandemia del nuevo coronavirus. Para eso, activamos el concepto de mediatización aplicado a la religión, discutido por Martino (2016), así como la relación entre la Iglesia Católica y la Comunicación presentada por Puntel (2011). Para promover una comparación de los cambios que ocurrieron, utilizaremos el estudio de Cunha (2017) sobre las estrategias de medios que fueron activadas por la parroquia en 2017 para luego hacer las aproximaciones necesarias con el contexto de aislamiento social impuesto por la pandemia de Covid-19 en el primer semestre de 2020. Después de todo, no se pretende responder ninguna pregunta al respecto, sino presentar el escenario experimentado en esta comunidad y, a partir de ellos, indicar posibles preguntas y trayectorias para la investigación.

PALABRAS CLAVE: Comunicación; Amazonas; religiosidad; estrategias de medios; aislamiento social.

Recebido em: 12.02.2020. Aceito em: 14.04.2020. Publicado em: 01.05.2020. 




\section{Introdução}

Com o avanço da pandemia do novo corona vírus no mundo as relações pessoais sofreram alterações que conduziram para uma maior utilização de meios digitais para a comunicação. Seja pelo medo de se contaminar ou a partir dos decretos de isolamento social, a internet passou a ser o ambiente de encontro para muitas pessoas. Shows, encontros, eventos, circulação de pessoas e tantas outras formas de encontro passaram a acontecer online, afim de evitar ao máximo os encontros presenciais.

No que diz respeito à relação entre igreja e fiéis não foi diferente. Esse estudo tem o propósito de produzir um relato de experiências, apresentando as alterações que estão acontecendo nas estratégias midiáticas adotadas pela paróquia São João Batista, instalada no município de Presidente Médici, no interior do Estado de Rondônia. A motivação deste artigo parte da percepção de que existe um movimento acerca da utilização das estratégias midiáticas utilizadas pela Igreja Católica após o isolamento social.

De modo geral é possível perceber que a Igreja Católica do mundo tem buscado uma nova forma de chegar até seus fiéis e por conta da pandemia isso implica no uso de aparatos de comunicação, os mais diferentes possíveis, mas sempre com a finalidade de garantir a prática da fé católica a partir da manutenção dos seus ritos, ainda que sob novas condições.

Para isso retomaremos uma pesquisa anterior (CUNHA, 2017) a respeito das estratégias midiáticas na Paróquia São João Batista de Presidente Médici. A partir do cenário abordado em 2017 poderemos estabelecer um comparativo entre a situação encontrada nesta comunidade católica antes da pandemia e as alterações que estão ocorrendo neste período.

Por se tratar de um relato de experiências, este artigo não pretende ser conclusivo por conta das alterações que ainda estão acontecendo dentro da comunidade e por conta do período de 


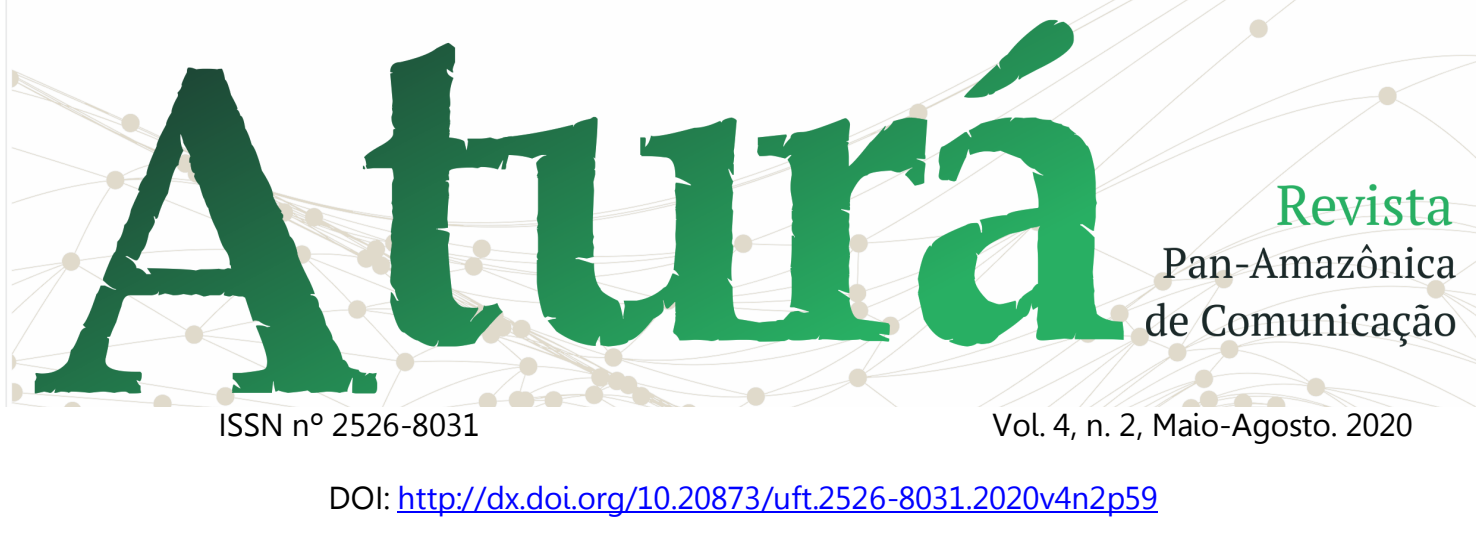

isolamento social. Grande parte do que está exposto deste artigo é fruto de observação pessoal e relatos de mídia, e um processo ainda em andamento, que, pode-se inferir, vai provocar profundas alterações nos modos de expressão de fé religiosa, de modo geral e, no que nos propomos abordar, nas práticas de fé católica em particular.

\section{Midiatização da Religião}

Segundo Martino (2016, p. 36) a Midiatização pode ser entendida como "um movimento de articulação das mídias nos processos sociais, com a consequente alteração de práticas e significados "mediados", isto é, que ocorrem na mídia". Para o autor a Midiatização acontece quando os processos sociais assumem novas configurações, ganhando outras formas. Um exemplo é a transmissão de um culto religioso na televisão - a missa - sem a alteração de nenhuma estrutura, nem das práticas, não é a Midiatização da missa, mas sim a mediação. Mas se a prática religiosa, no caso a missa, vier a ser transformada para se encaixar nos moldes de um programa de TV, então pode-se dizer que houve uma Midiatização da prática religiosa.

Os indícios da relação entre mídia e religião se dão a partir de 1940 nos Estados Unidos, quando sacerdotes católicos e pastores passaram a utilizar dos meios de comunicação, na época o rádio, cinema e impresso, adaptando sua mensagem para cada tipo de mídia, com - objetivo de transmitir mensagens religiosas (MARTINO, 2016). Com a midiatização das relações e práticas sociais, a Igreja começa a ser pressionada pela nova configuração social a se adequar à nova realidade, onde os meios de comunicação surgem e reconfiguram a sociedade. Porém, enquanto as igrejas protestantes, por exemplo, se abriram à mídia de forma instantânea, a Igreja Católica enxergava os meios de comunicação de forma apocalíptica.

A Igreja Católica levou anos para permitir que as comunicações pudessem ser utilizadas, mais especificamente as discussões sobre o tema tiveram início 


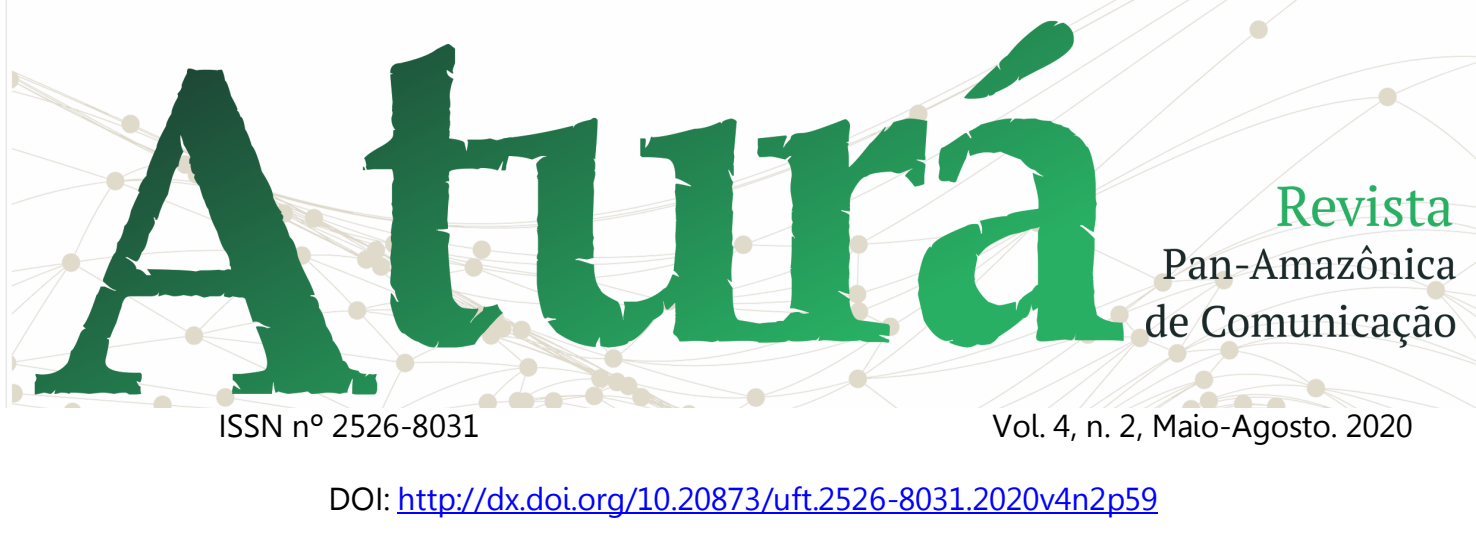

por volta de 1878 e foram se desenvolvendo de forma lenta e gradual até 1957 quando, segundo Puntel (2011), Igreja Católica se aprofunda sobre o tema e lança pela segunda vez uma encíclica (Miranda Prorsus, 1957) para falar especificamente sobre comunicação. 0 comportamento da igreja perante o surgimento das novas mídias foi se alterando conforme o tempo. Essa transformação do pensamento da Igreja é percebida a partir das encíclicas e decretos que o Vaticano normatiza para toda a Igreja. Joana Puntel salienta que a relação da Igreja Católica com a comunicação pode ser dividida em três fases. A primeira fase é caracterizada, segundo a mesma autora, por um comportamento da Igreja orientado para o exercício da censura. Esta fase ocorre na época em que a Igreja Católica detinha a produção do saber, não só teológico, e a sua difusão na sociedade no Século XV (PUNTEL, 2011).

A segunda fase é caracterizada por uma preocupação da Igreja com a mídia e a sua aceitação desconfiada (PUNTEL,
2011), que resultou na publicação de Encíclicas que dialogam sobre o tema. Em 1936 a Igreja apresentou uma Encíclica falando sobre o cinema. A Vigilanti Cura teve como objetivo traçar diretrizes para que a Igreja soubesse como agir perante o cinema. No documento o Papa Pio XI argumentava que em diversas reuniões que tivera com os empresários do campo do cinema, a Igreja se preocupou com os ensinamentos apresentados por este grande meio. Já em 1957, a Igreja Católica apresenta a preocupação não só com o cinema, mas com o rádio e a televisão. Em sua Encíclica Miranda Prorsus (1957), o Papa Pio XII fala sobre a maravilha do aperfeiçoamento das tecnologias, mas também da preocupação em sua forma de utilização.

A terceira fase acontece quase dez anos depois de ser lançada a Encíclica Miranda Prorsus, quando a Igreja lança um decreto sobre a comunicação. De repente a Igreja começa a adaptar-se ao mundo e as novas tecnologias que já estavam sendo utilizadas pela sociedade. O decreto Inter Mirífica (1966) além de 


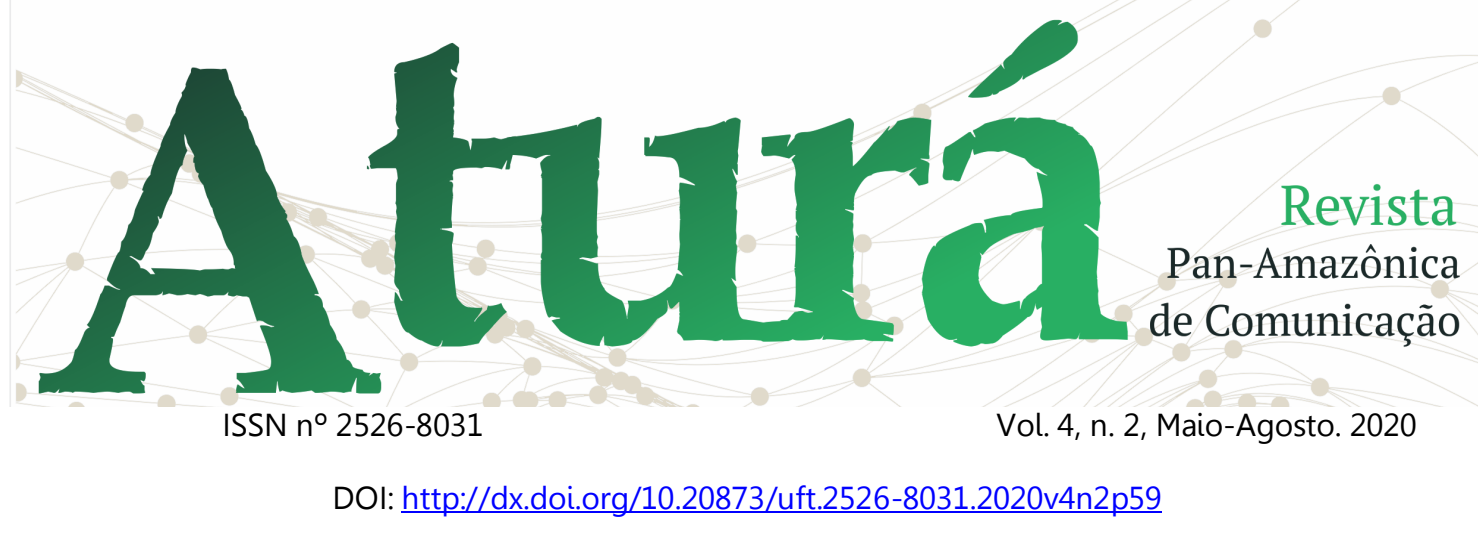

ressaltar que a comunicação pode ser Em 1992 a Igreja lança a Encíclica usada tanto para o bem, quanto para o mal, defende que os veículos de comunicação sejam utilizados para a divulgação e formação dos valores morais.

A partir disso muita coisa mudou na Igreja. Na década de 1970 a Igreja lançou uma Encíclica para falar sobre a evangelização, que teve um trecho reservado para os meios de comunicação, que diz sobre a potencialidade das mídias na propagação do evangelho. A Encíclica Comunio et Progressio foi publicada na quinta comemoração do dia mundial da comunicação em 23 de maio de 1971. Nela, a Igreja reafirma a importância do uso das mídias para a formação da sociedade. Nesta carta a Igreja trata também do que Martino (2016) chama como uma característica da Midiatização que é a apropriação das linguagens próprias dos meios para a comunicação da mensagem, e a transformação na forma de comunicar articulando práticas e ações comuns entre elas.

\section{Isolamento social e novas práticas religiosas}

De forma gradual, principalmente após a publicação das encíclicas e decretos a respeito das comunicações, a Igreja Católica foi se adaptando e cada vez mais fazendo usos da mídia a fim de 


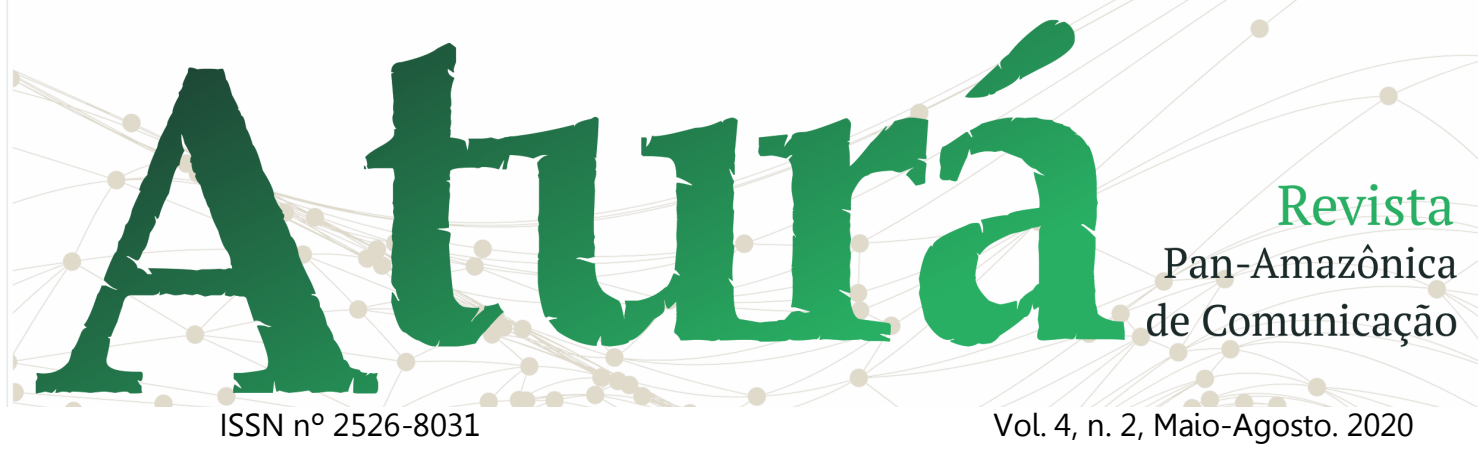

DOI: http://dx.doi.org/10.20873/uft.2526-8031.2020v4n2p59

divulgar a fé e promover o sentimento de pertença dos fiéis. Porém, essa adaptação, assim como a aceitação da Igreja Católica, aconteceu de forma gradual, chegando a ser até tardia quando comparada com as igrejas protestantes. Em "[...] 1980 as igrejas Universal do Reino de Deus e a Igreja da Graça já faziam dos meios de comunicação um elemento central de suas atividades $[. . .]^{\prime \prime}$, enquanto a Igreja Católica "[...] revia seus conceitos sobre a comunicação" (MARTINO, 2016, p.22). O uso da comunicação não era uma regra, mas uma orientação da igreja, como é possível perceber através dos decretos e dos documentos papais. Desse modo, ainda existem muitas realidades que não contemplam o uso das comunicações dentro da Igreja Católica no mundo.

Com o início da pandemia do novo coronavírus no mundo a Igreja precisou se adequar às normas estabelecidas pelo Ministério da Saúde, o que resultou na proibição de celebrações ${ }^{3}$ e cultos

${ }^{3} \mathrm{~A}$ celebração aqui possui o significado de celebrar algo. No caso da igreja católica, na missa é feita a celebração da paixão morte e ressurreição. $O$ padre assume a pessoa de cristo, abertos com a participação dos leigos, a fim de evitar a disseminação do vírus entre as pessoas. Algumas dioceses (AQUINO, 2012) ${ }^{4}$ chegaram a dispensar os fiéis católicos da obrigação de participar da missa dominical e em dias de festa por conta do avanço da pandemia do Covid-19 (NOTA OFICIAL, 2020). Segundo o direito canônico da Igreja (AQUINO, s/d) o católico possui como dever participar das missas dominicais e dias de festa 5 .

\footnotetext{
"persona christi" quando faz a consagração da eucaristia. Por conta da falta de sacerdotes no mundo, alguns leigos são formados para fazer a celebração apenas da palavra e a distribuição da eucaristia. Neste caso se chama "celebração da palavra". Na celebração da palavra não existe a consagração da eucaristia. Porém, ambas são celebrações da fé.

4 "Diocese é o nome de uma divisão territorial estabelecida pelo Papa para delimitar a área de atuação e governo de um Bispo. Só o Papa pode nomear bispos e estes estão ligados diretamente a ele."

5 "Este é o terceiro mandamento da Lei de Deus, que, orienta os cristãos católicos, guardarem dias especiais em celebração ao Mistério Pascal de Jesus. Este mandamento está diretamente ligado à uma orientação das Leis Canônicas que são os Dias de Preceito, ou Dias de Guarda dentro do Calendário Litúrgico da Igreja e servem para orientar os cristãos para os dias dedicados especialmente a Deus". Texto disponível em: $<$ https://www.paieterno.com.br/2019/10/31/vocesabe-o-que-sao-dias-de-preceitos-ou-de-guarda/>
} 


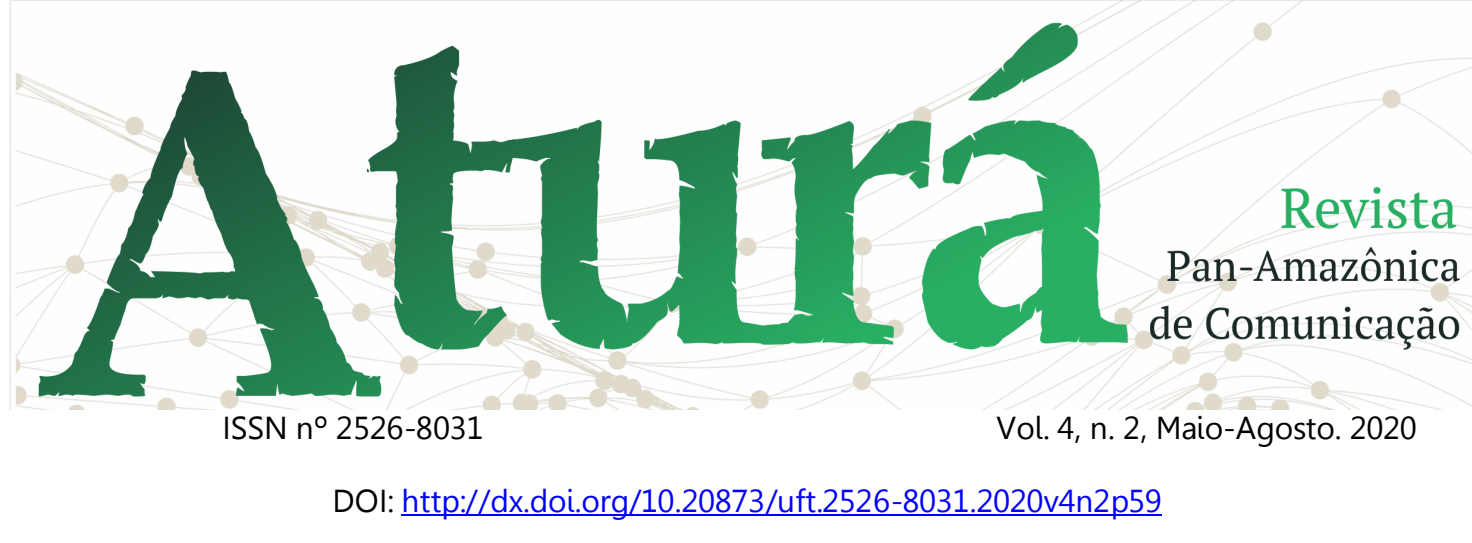

A Semana Santa é o evento mais importante para o cristão católico, pois é celebrado a paixão, morte e ressurreição de Jesus Cristo. Ela começa no domingo de ramos e segue até o domingo de páscoa. Para os católicos essa data é especial pois é na ressurreição que está a centralidade da fé católica. É considerada também a festa principal da Igreja, sendo assim um dia de preceito, que por conta do coronavírus, precisou ser celebrada sem a presença dos fiéis.

No Brasil, após o início a crise, diversos bispos acolheram as recomendações do Ministério da Saúde. Com esse cenário a Igreja Católica passou a investir mais no uso da comunicação, principalmente a digital. As recomendações eram para que os católicos assistissem a missa através dos canais de televisão. Alguns sacerdotes utilizaram suas próprias redes sociais e começaram a produzir conteúdo, como o caso de um padre (ALOISIO, 2020) do sertão da Bahia que possuía em seu Instagram cerca de 106 mil seguidores e as suas missas, transmitidas pela rede social, chegavam à marca de mil participantes simultâneos.

A iniciativa de realizar a transmissão das missas pelas redes sociais não foi uma recomendação da CNBB ou do Papa, mas sim um movimento que foi surgindo em todo o mundo devido as necessidades e a possibilidade de enfrentamento do isolamento social. Para alguns padres, principalmente os mais novos de idade e os que tinham o auxílio de membros da Pastoral da Comunicação ${ }^{6}$, a realização de lives celebrando a missa não era algo muito complexo. Por outro lado, alguns sacerdotes chegaram a virar meme na internet, como um padre do interior de São Paulo que sem querer adicionou filtros engraçados na transmissão de uma benção através da sua página no

6 "O Diretório de Comunicação da Igreja no Brasil (Documento 99 da CNBB) define a Pastoral da Comunicação (Pascom) como eixo transversal de todas as pastorais da Igreja. Em sua missão, deve irradiar ações próprias do campo da comunicação com sentido pastoral, as quais ganham sentido na medida em que colaboram com a ação evangelizadora eclesial." Texto dispinivel em: <https://www.cnbb.org.br/pascomtrabalho-de-comunicacao-na-igreja-e-estar-aservico-da-evangelizacao/>. 


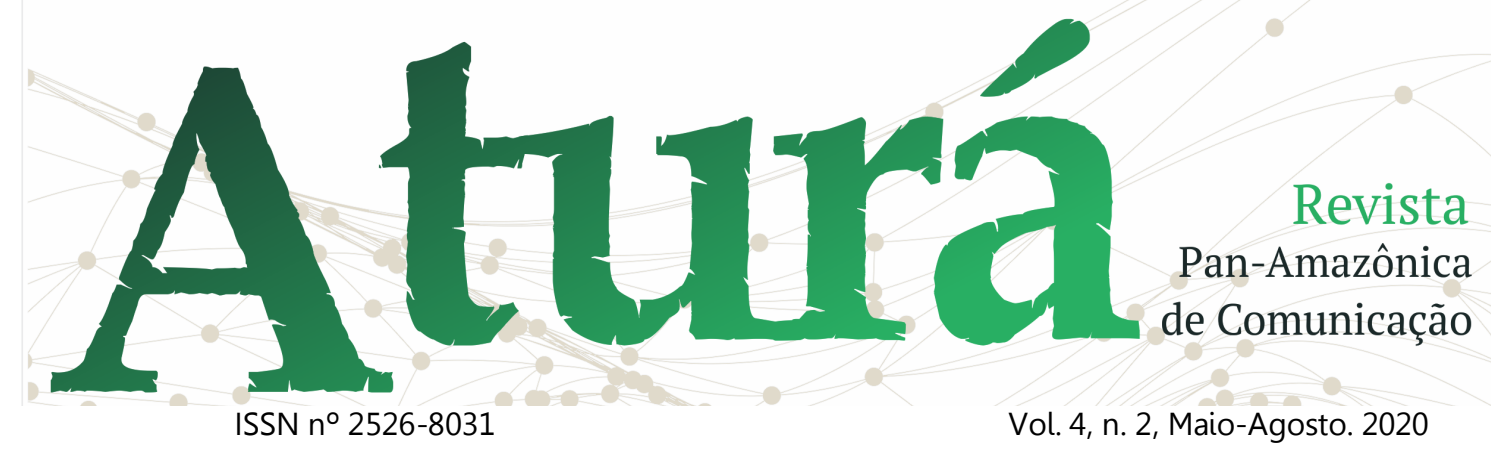

DOI: http://dx.doi.org/10.20873/uft.2526-8031.2020v4n2p59

Facebook. Por estar usando a câmera traseira do celular ele só descobriu o acontecido após acabar a transmissão (PADRE FAZ, 2020).

Em outros lugares no Brasil os padres incentivaram os fiéis a enviarem fotos para que fossem colocadas nos bancos das igrejas (MARKMAN, 2020). Se por um lado há a impossibilidade de estar juntos, no outro existe a solidão dos sacerdotes que se encontraram fisicamente sozinhos. Uma representação dessa solidão dos padres pode ser observada por uma imagem que circulou - mundo do Papa Francisco (PAPA FRANCISCO REALIZA, 2020) concedendo a bênção urbi et orbi ${ }^{7}$, sozinho a contemplar a imagem de Jesus crucificado.

Em alguns países, canais de TV católicos foram criados para dar conta

\footnotetext{
7 "A expressão latina Urbi et Orbi significa "para a cidade [de Roma] e para o mundo". É o nome da bênção que é dada pelo Papa, da sacada central da Basílica São Pedro. Trata-se, afinal, de uma bênção solene que concede a indulgência plenária, ou seja, a remissão das penas dos pecados já perdoados." Disponível em: $<$ https://www.acn.org.br/papa-francisco-concedeindulgencia-plenaria-para-a-oracao-de-27-demarco/>
}

das necessidades propostas neste tempo. É o caso da Televisão Católica Ukweli (que significa verdade) criada no Quênia ainda no início da pandemia (QUENIA IGREJA, 2020). Ou a TV católica da Romênia, a TVR3 criada recentemente "[...] para responder às necessidades, sobretudo espirituais dos fiéis, e manter unida e viva a comunidade eclesial, a Igreja criou uma emissora de televisão e um programa com vídeo nas redes SOciais" (CORONAVÍRUS FEZ NASCER, 2020).

No Brasil as TVs católicas tiveram um aumento significativo de audiência (CRESCE AUDIÊNCIA, 2020). Em uma entrevista concedida ao site do Conselho Nacional de Bispos do Brasil $^{8}$, o

\footnotetext{
8 "A Conferência Nacional dos Bispos do Brasil (CNBB) é a instituição permanente que congrega os Bispos da Igreja católica no País, na qual, a exemplo dos Apóstolos, conjuntamente e nos limites do direito, eles exercem algumas funções pastorais em favor de seus fiéis e procuram dinamizar a própria missão evangelizadora, para melhor promover a vida eclesial, responder mais eficazmente aos desafios contemporâneos, por formas de apostolado adequadas às circunstâncias, e realizar evangelicamente seu serviço de amor, na edificação de uma sociedade justa, fraterna e solidária, a caminho do Reino definitivo." Texto disponível em: <https://www.cnbb.org.br/quem-somos/>
} 


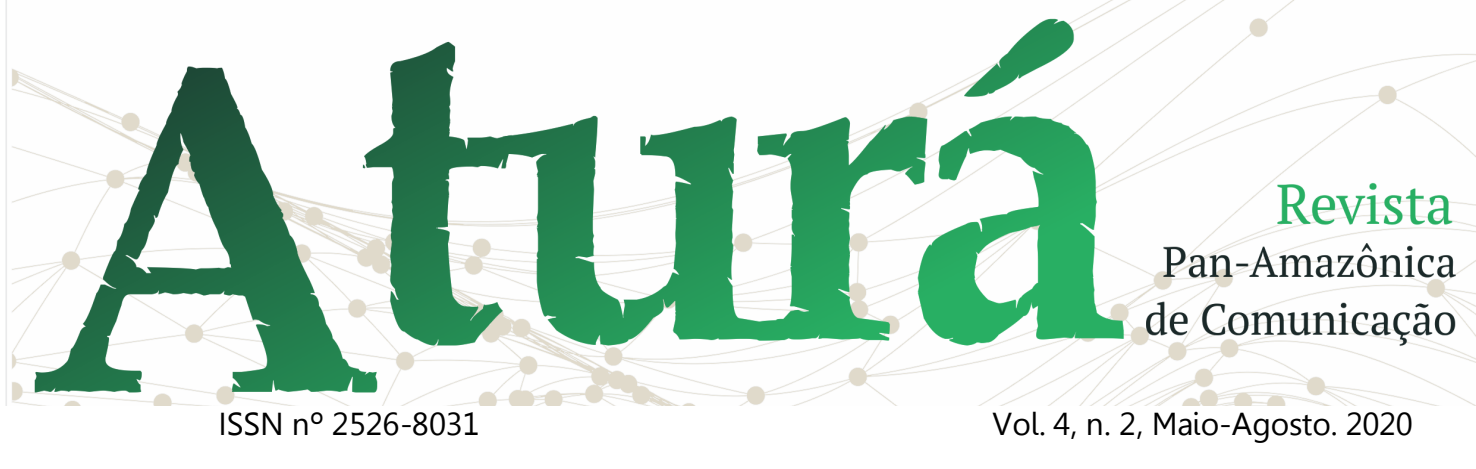

DOI: http://dx.doi.org/10.20873/uft.2526-8031.2020v4n2p59

coordenador da Signis ${ }^{9}$ Brasil TV e diretor de expansão, engenharia e almoxarifado da Associação Evangelizar é Preciso ${ }^{10}$, Geizom Sokacheski, afirmou que

Aumentos que são percebidos pelos telefones das emissoras que não param e em muitas tem até travado pelo excesso de volume de ligações e ou recebimento de e-mails, praticamente todos as emissoras relatam que tiveram de contratar mais acessos de streaming de TV e áudio para seus sites e seus aplicativos. (CRESCE AUDIÊNCIA, 2020)

O que se observa é que de modo geral a Igreja católica tem buscado, neste

9 "Signis é uma associação católica internacional, com reconhecimento Pontifício. Iniciada em 2001 com a convergência das Associações católicas anteriores, relativas à imprensa, cinema e vídeo, rádio, televisão e profissionais da comunicação." Texto disponível em: < https://signis.org.br/2017/userfiles/ckeditor/Signis \%20Brasil/Relatório_final_Signis_brasil.pdf >

10"A Associação Evangelizar É Preciso foi fundada pelo padre Reginaldo Manzotti em 2005. É uma instituição sem fins lucrativos que tem como objetivo evangelizar pelos meios de comunicação. Atualmente, a Associação Evangelizar É Preciso é responsável pela programação da Rede Evangelizar de Comunicação, que é composta pela Rádio Evangelizar: AM 1060, AM 1430 e ondas curtas, FM 90.9 e FM 99.5, e pela TV Evangelizar." Texto Disponível em $:<$ https://www.padrereginaldomanzotti.org.br/asso ciacao/> tempo de pandemia, soluções para resolver o distanciamento causado pelo isolamento social. A medida encontrada está na utilização dos meios de comunicação como ambiente para a promoção da fé cristã entre os fiéis. Tanto no Brasil como no mundo essas medidas já estavam sendo adotadas, porém de forma gradual. A partir do cenário imposto pelo isolamento social houve um aumento significativo na busca da utilização das mídias como espaços de evangelização.

\section{Paróquia São João Batista e as estratégias} midiáticas.

Antes da pandemia do novo coronavírus, o cenário encontrado na Igreja Católica do município de Presidente Médici, interior do Estado de Rondônia, se baseava em estratégias midiáticas distintas, diferentes uma da outra, mas que não eram opostas e sim complementares. A partir das mudanças socioculturais que aconteceram no primeiro semestre de 2020 é possível perceber alterações significativas nos 


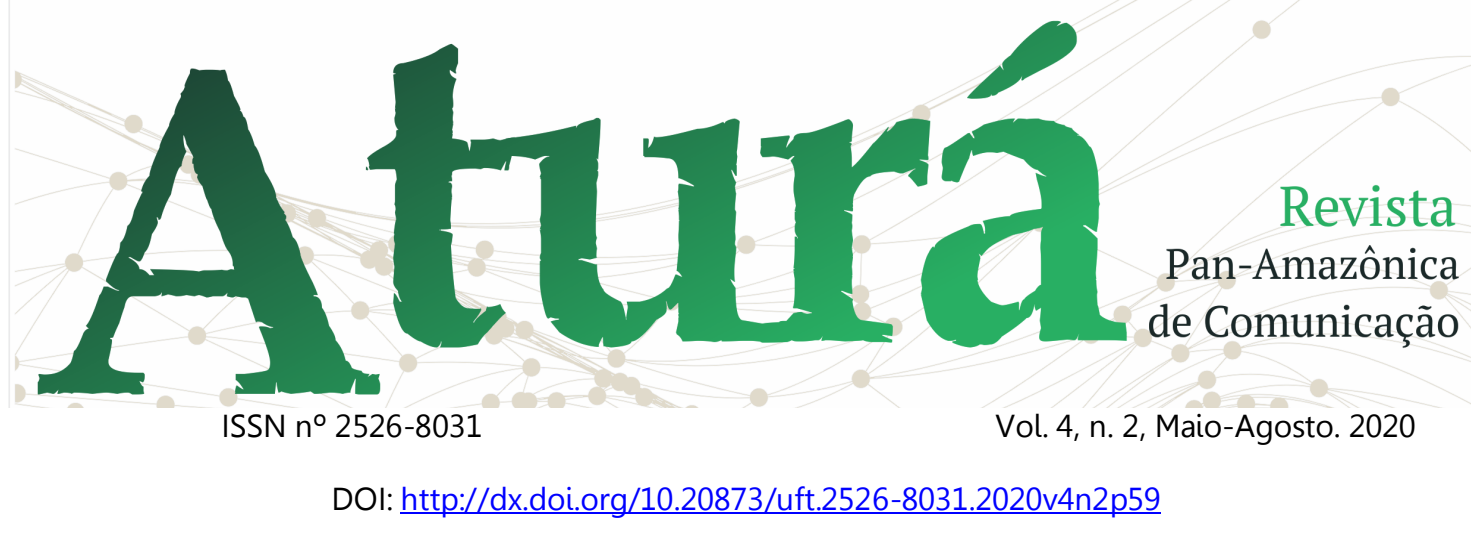

usos de estratégias midiáticas pela paróquia São João Batista.

Em trabalho anterior (CUNHA, 2017) verificamos que a primeira estratégia midiática acionada pela paróquia foi o rádio, com a criação de dois programas de rádio, o Mensageiro da Paz e Jesus Te Ama, ambos criados nos anos 1990 e que continuam no ar até hoje, inicialmente organizados e apresentados pelos membros da comunidade. O programa Mensageiro da Paz vai ao ar de segunda à sexta-feira das $6 \mathrm{~h}$ às $7 \mathrm{~h}$ da manhã e possui um caráter mais informativo. O programa Jesus te Ama, foi criado pelos católicos leigos ${ }^{11}$ que pertenciam ao Movimento de Renovação Carismática Católica (RCC), e vai ao ar todos os sábados ao meio dia, possuindo um caráter mais oracional.

O rádio também foi a opção adotada pela paróquia para o programa

11 "Os leigos, ou seja, os fiéis que não receberam a Sagrada Ordenação nem fizeram votos públicos dos conselhos evangélicos, são chamados por Deus a assumir com grande amor e generosidade sua missão específica na Igreja e no mundo." Texto disponível em: < https://www.cnbb.org.br/avocacao-do-leigo/>

Hora do Ângelus ${ }^{12}$, que é transmitido todos os dias às $18 \mathrm{~h}$, e também para transmissão da missa nas quintas-feiras e aos domingos. Neste cenário o rádio podia ser considerado o carro chefe das atividades midiáticas que estavam sendo desenvolvidas pela paróquia, isso porque a utilização do rádio como estratégia sofreu influência do processo de colonização agrícola que deu origem ao Estado de Rondônia (CUNHA, 2017).

A segunda estratégia midiática adotada pela paróquia se dava através do uso da internet, e tinha impactos crescentes a partir de uma maior utilização desse suporte na zona rural do município. A rede social Facebook e o aplicativo de mensagens Whatsapp eram as ferramentas acionadas a partir dessa estratégia. $O$ gerenciamento de ambas se dava pelo padre Juviano Pereira, que anteriormente exercia a função de vigário da paróquia, isto é, não tinha

\footnotetext{
12 Programa de oração veiculado no rádio todos os dias às 18h. Esse programa já existida deste 2017 quando foram identificadas as estratégias midiáticas utilizadas pela paróquia São João Batista.
} 


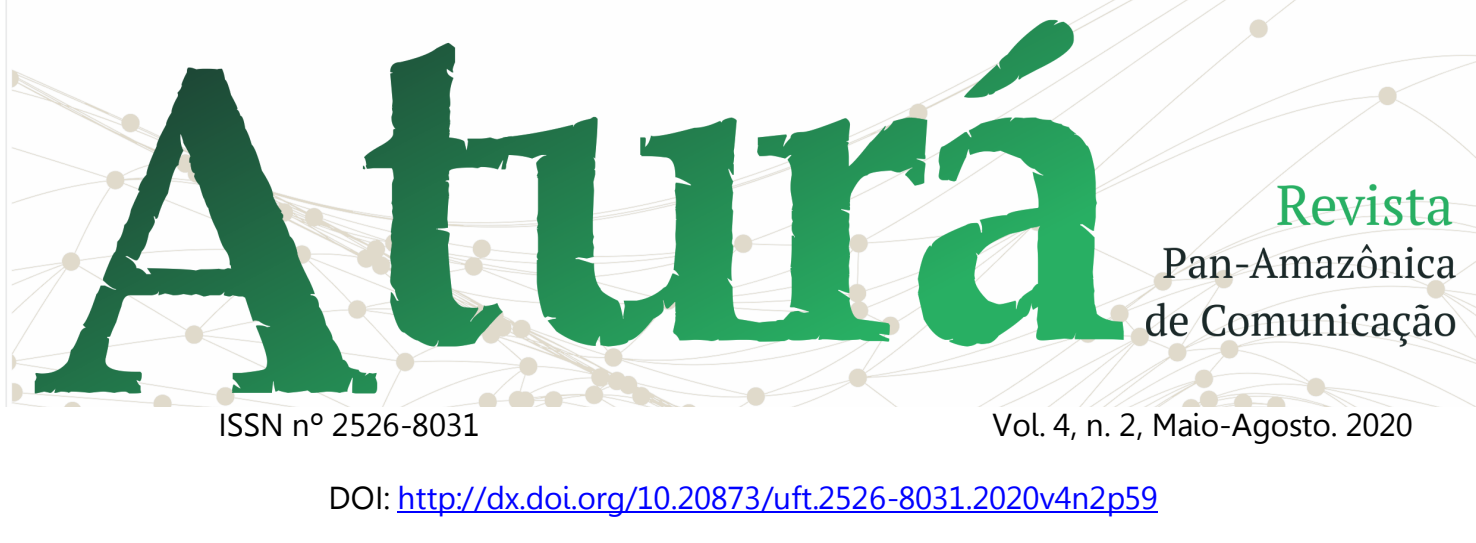

responsabilidade administrativa da paróquia. Atualmente o padre está como pároco da paroquia São João Batista, assumindo assim as responsabilidades administrativas que diz respeito às comunidades. A página do Facebook da paróquia era usada, basicamente, para a publicação de fotos ou anúncios dos eventos realizados. Já o Whatsapp tinha o objetivo de entrar em contato de forma direta e mais rápida com os coordenadores das comunidades que pertenciam à paróquia.

As mudanças nas estratégias comunicacionais da paróquia de Presidente Médici começaram a sofrer alterações a partir das mudanças causada pela pandemia do novo coronavírus. O cenário encontrado na Paróquia São João Batista não é diferente do que se observou no restante do país sacerdotes e paróquias que começaram a se valer do uso das mídias sociais para se comunicar com suas comunidades e para celebrar missas on-line. A iniciativa de começar a transmitir a missa diária partiu do Padre Juviano que iniciou a transmissão no dia 19 de março, dois dias após o governo estadual ter decretado estado de calamidade pública e logo em seguida a quarentena com distanciamento social.

A partir daí as transmissões das missas diárias passaram a ser algo recorrente. A participação também aumentou. Os registros de audiência das missas começaram a ser feitos pelos autores deste artigo a partir da segunda missa transmitida on-line. Na sexta-feira 20 de março, a missa foi transmitida às $18 \mathrm{~h}$ e teve cerca de 50 acessos simultâneos. Na missa que foi transmitida pela paróquia no domingo, 22 de março, houve acessos simultâneos de 100 pessoas. Antes da pandemia o número de participantes da missa, considerando apenas as celebrações realizadas na igreja matriz no domingo de manhã e a noite, poderia chegar a cerca de mil fiéis presentes.

O número de participação online continuou a crescer, chegando a 198 acessos simultâneos nove dias após 0 início das transmissões, a partir daí outros 


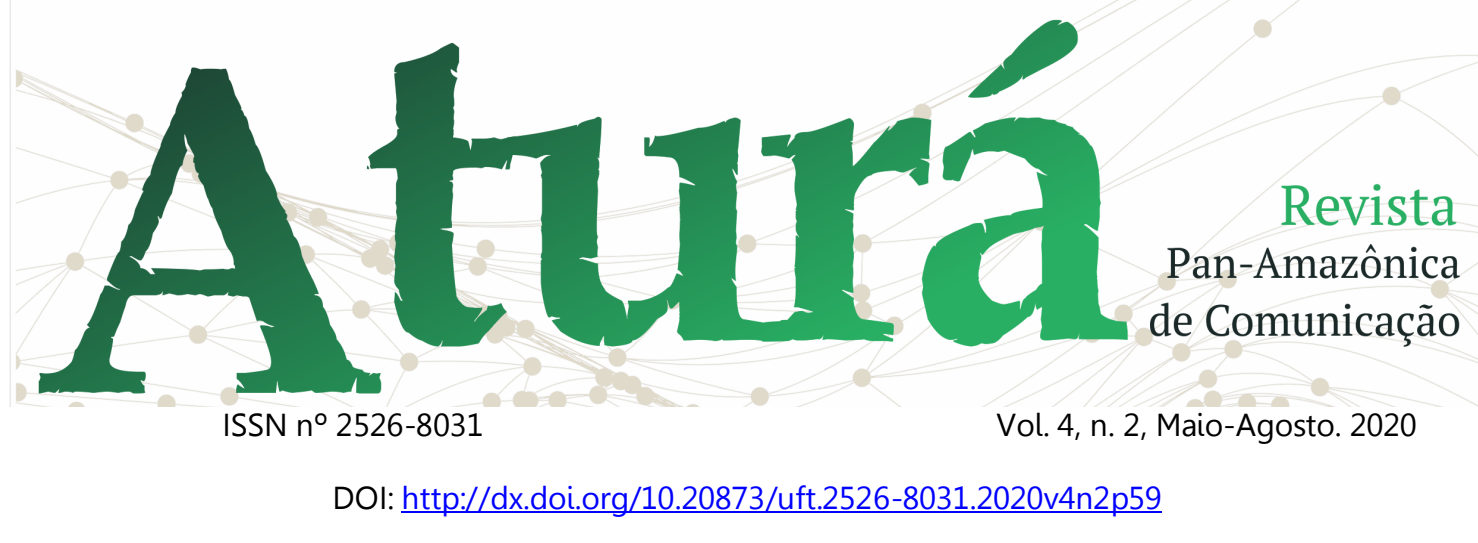

programas foram se estabelecendo, principalmente com a utilização da internet. O padre Juviano decidiu criar um momento de oração diário, às $15 \mathrm{~h}$, para rezar com os seus paroquianos. Inicialmente o momento de oração era transmitido pelo Facebook, pois de modo geral era o recurso que eles, os padres e irmãos da congregação de que o padre pertence, sabiam operar. Esse momento de oração era feito antes por cada membro da comunidade católica de forma individual. No início da quarentena a paróquia teve que suspender esse momento por conta das recomendações governamentais e diocesanas, então a saída encontrada foi a transmissão pelo Facebook da paróquia.

Mesmo após o relaxamento das medidas de isolamento social no município e a reabertura da igreja após a quarentena decretada pelo Governo do Estado, o momento de oração continua acontecendo e sendo transmitido, agora não mais na igreja, mas em uma sala de catequese utilizada especificamente para isso.

De forma gradual os recursos para a transmissão desses momentos começaram a melhorar, pois no início as lives eram feitas apenas com um smartphone, sem microfone ou tripé. $\mathrm{O}$ suporte utilizado para estabilizar o celular para a transmissão era um pedestal de microfone. Com o tempo a paróquia recebeu a doação de dois tripés e conseguiu, emprestado com os membros da igreja, três câmeras do tipo webcam para utilizar.

A captação de áudio também passou por uma mudança quando começaram a captar o áudio diretamente da mesa de som da paróquia, isso porque normalmente utilizavam a captação de áudio do celular que era muito baixa. As transmissões então, com sua melhora gradual, passaram a ser realizadas com a utilização de uma plataforma de streaming de vídeo, o Youtube. Uma das salas de catequese ${ }^{13}$ que não está sendo utilizada no momento por conta da pandemia do coronavírus, se transformou

\footnotetext{
${ }^{13}$ Formação dos jovens e adultos católicos para receber os sacramentos.
} 


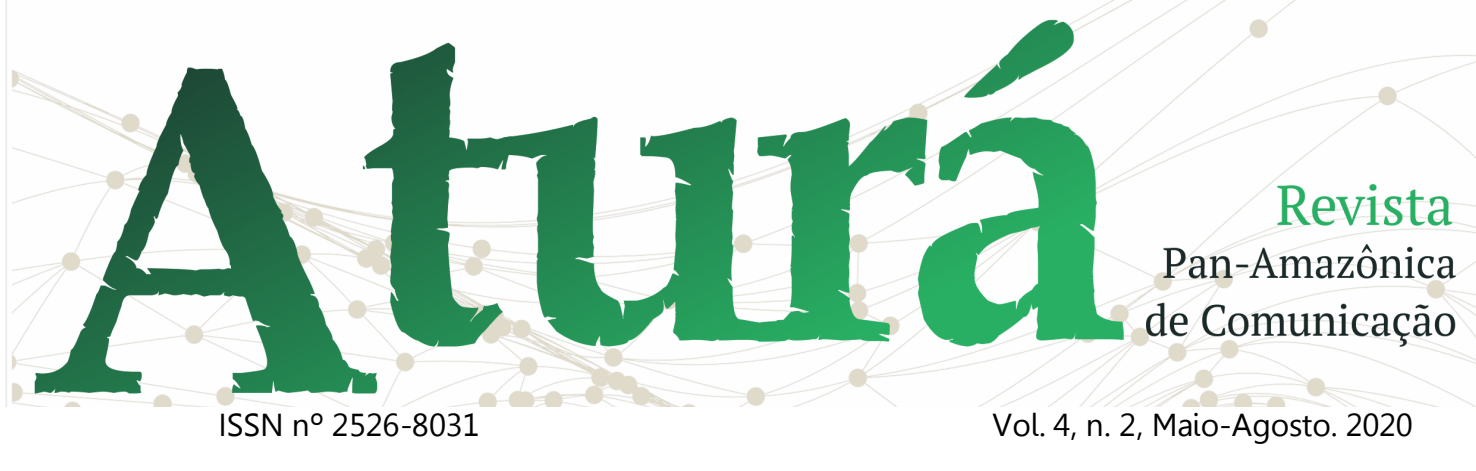

DOI: http://dx.doi.org/10.20873/uft.2526-8031.2020v4n2p59

em um estúdio para as lives. Nesse ambiente eles gravam as formações e até mesmo momentos de oração.

Para além da transmissão da missa e de momentos de oração a paróquia começou a realizar formações e momentos de estudos sobre diversos assuntos relacionados à Igreja Católica. Esses estudos e formações são gravados e postados em um dia específico. Houve também a criação de um programa que ficou conhecido como " $A$ palavra do pároco", porém não teve continuidade.

Outros dois programas que começaram a ser realizados na paróquia são as reuniões dos movimentos Apostolado da Oração ${ }^{14}$ e Legião de Maria15. Como os dois movimentos

\footnotetext{
${ }^{14}$ Apostolado da Oração (AO), um Movimento Eclesial, que procura viver a espiritualidade apostólica e Eucarística, brotada do Sagrado Coração, e fundamentada na releitura do Mistério da Paixão de Jesus." Disponível em: $<$ https://diocesedesaojoaodelrei.com.br/vocesabe-o-que-e-o-apostolado-da-oracao/>

${ }^{15}$ A Legião de Maria é uma associação de leigos católicos, sob a proteção e intercessão de Nossa Senhora e com aprovação da Igreja, que pela oração e pelo trabalho apostólico ativo, destina-se à evangelização e à santificação dos homens, para a glória de Deus. Para tornar essa missão possível, os legionários buscam também a santificação pessoal, afim de se tornarem cada
}

possuem, em sua maioria, a participação de pessoas idosas que pertencem ao grupo de risco, a paróquia decidiu fazer a transmissão das reuniões dos membros de forma online.

\section{A paróquia também encontrou no} uso da internet uma saída para manter a catequese, que por conta do da necessidade de isolamento social está acontecendo através de vídeo conferência. As atividades são enviadas para os membros por e-mail, ou WhatsApp, a fim de dar continuidade na formação. Também foram realizadas durante o período de distanciamento duas carreatas que foram que ficaram conhecidas como passeio eucarístico, com o objeto de maior importância para os católicos, a eucaristia ${ }^{16}$. A carreata foi transmitida em tempo real pelo Facebook e Youtube da paróquia.

\footnotetext{
dia mais aptos a levar Cristo ao mundo. Disponível $<$ https://www.legiaodemaria.org.br/o-que-e-alegiao-de-maria>

${ }^{16}$ Segundo a tradição da igreja católica a eucaristia é o corpo de jesus dado por ele mesmo na última ceia com os discípulos.
} 


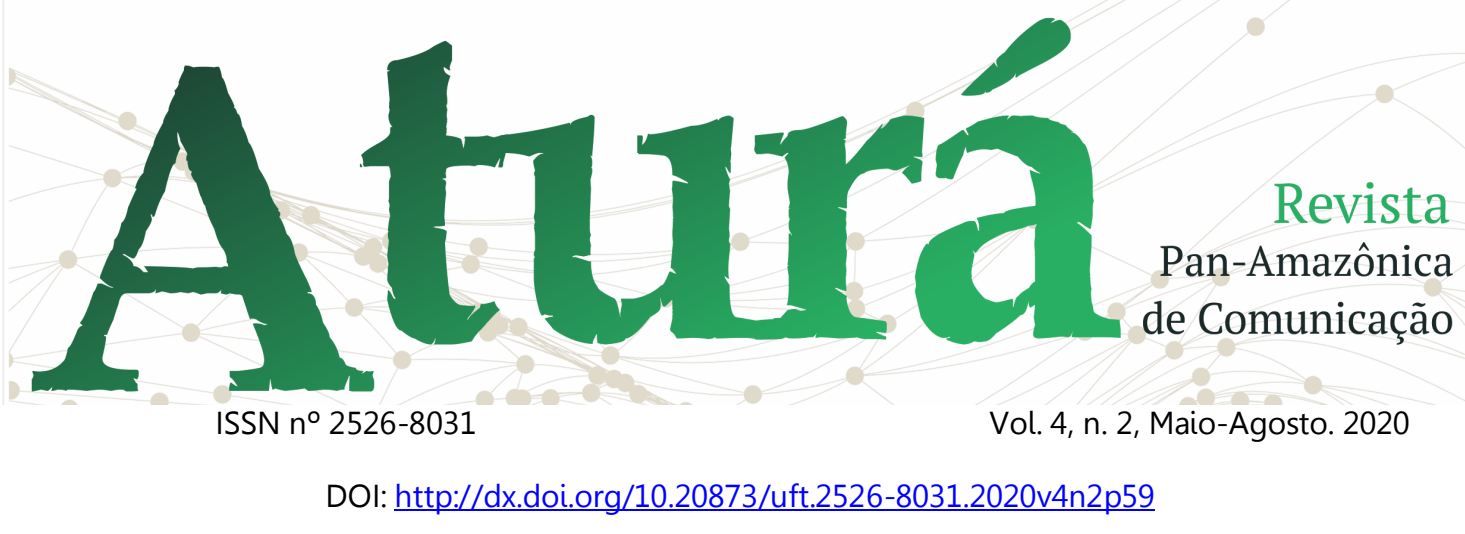

Os programas transmitidos através do rádio continuam os mesmos desde 2017. Tanto o Mensageiro da Paz quanto - Jesus Te Ama não sofreram alteração neste período de pandemia, muito menos as transmissões da missa e a Hora do Ângelus. A única coisa que se pode destacar de diferente nesta pandemia na utilização do rádio se dá a partir da inserção de outros horários durante a Semana Santa para que a missa pudesse ser transmitida.

É possível perceber que a partir das observações feitas em pesquisa anterior (CUNHA, 2017) o rádio podia ser considerado a estratégia comunicacional mais relevante na paróquia de Presidente Médici. Mesmo já havendo um perfil no Facebook e a uma conta no Youtube da paróquia, além de perfil na rede social Instagram, a internet era usada apenas como uma forma de publicizar o que estava sendo realizado pela comunidade. O cenário encontrado em 2020 é outro: a internet passa ser um lugar de atividade, um ambiente onde é possível encontrar e acompanhar todas as atividades que estão sendo realizadas em tempo real.

Com esse olhar, podemos dizer que atualmente a estratégia midiática mais acessada pela paróquia deixou de ser o rádio, o que não significa que ele deixou de possuir importância para a comunidade local, mas que a internet passou a ser a escolha preferencial por conta da pandemia do novo coronavírus, visto que para se realizar uma transmissão não se faz necessário sair de casa, enquanto para apresentar um programa de rádio é preciso se expor ao risco de sair de casa e ir até uma emissora, e isso diz respeito não apenas aos locutores, mas aos leigos que conduzem celebrações e ao pároco. Outro fator é a oportunidade de criar mais programas, e de forma gratuita, enquanto os programas realizados no rádio possuem custo financeiro para a paróquia.

As festividades da paróquia, como o Dia de Pentecostes, festa da igreja em que se comemora 50 dias após a pascoa e a vinda do espirito santo sobre os 


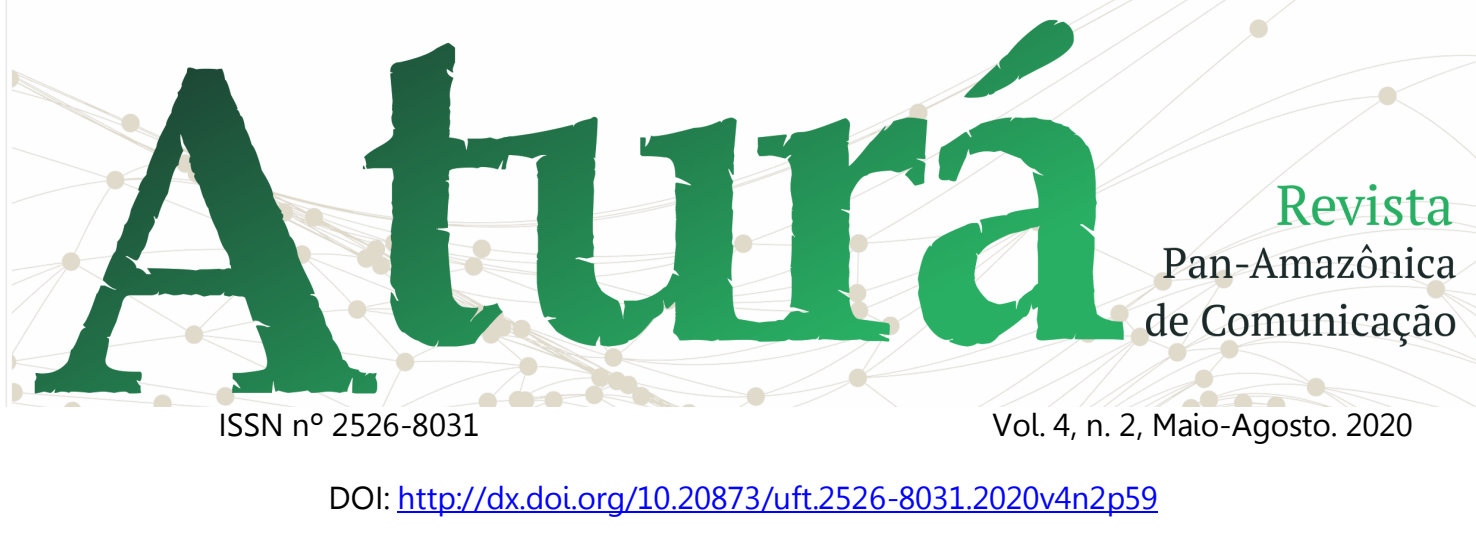

apóstolos de Jesus, e até mesmo a festa do padroeiro São João Batista, períodos em que normalmente são realizadas quermesses, com festival de danças e comidas típicas, por conta da pandemia começaram a ser realizadas através de lives. A Festa de Pentecostes teve uma live que ficou conhecida como Clamando em Casa, com duração aproximada de duas horas. Até a última semana do mês de junho de 2020 a live teve 1,8 mil visualizações no Youtube. Foi nesta live que a paróquia começou a utilizar um recurso para receber doações através da disponibilização de um $Q R$ Code fixado na transmissão de vídeo. A partir daí, toda missa passaria a ter esse recurso para quem quisesse fazer uma doação. A Festa do Padroeiro, que acontece no dia 24 de junho, teve o mesmo formato, com distribuição de prêmios, apresentações musicais e brincadeiras, tudo transmitido através do Youtube e Facebook.

No que diz respeito à iniciativa de utilizar estratégias midiáticas na paróquia São João Batista podemos perceber, a partir da pesquisa anterior realizada

(CUNHA, 2017), que os leigos membros da comunidade foram os responsáveis pela criação, organização e produção dos conteúdos que eram veiculados, principalmente os programas de rádio. Isso se dava através Pastoral da Comunicação e da organização dos leigos. Com o novo cenário provocado pela pandemia é possível perceber uma maior iniciativa partindo do pároco da cidade, juntamente com os membros da congregação de que ele faz parte.

O site da paróquia, que existia na época da pesquisa anterior (CUNHA, 2017), foi extinto, dando lugar prioritário para os usos das mídias sociais. O foco passou a ser a manutenção das redes sociais, seja por conta do público alvo, seja por conta da maior facilidade de administrar as redes sociais. A utilização do WhatsApp, que na pesquisa anterior (CUNHA, 2017), identificamos como sendo administrado pelo pároco, passou a contar com um número específico para a secretaria paroquial, administrado pelas secretarias da paróquia. Quem necessitar agendar horário para ir até a secretaria 


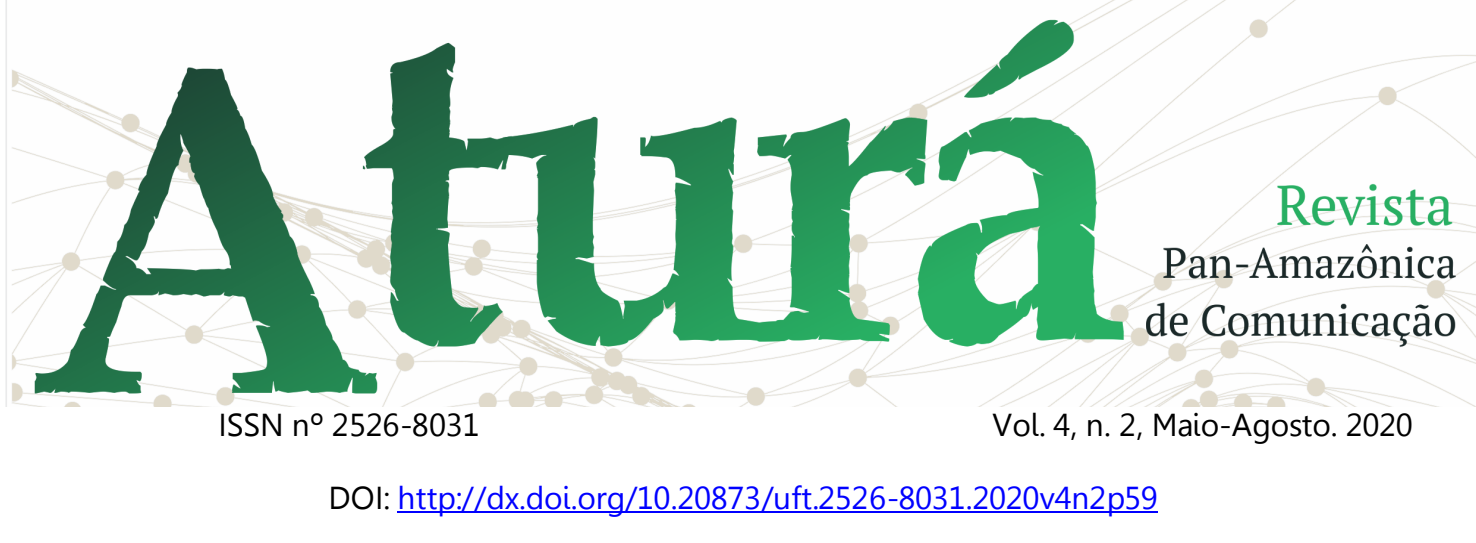

teria de fazê-lo pelo WhatsApp. Já os grupos paroquiais que existem no aplicativo, em sua maioria, são administrados pelo padre Juviano.

Ao lançar olhar sobre a realidade da Paróquia São João Batista, no interior de Rondônia, podemos perceber que a pandemia do novo coronavírus provocou uma mudança na relação da comunidade católica com as estratégias midiáticas acionadas por eles, de modo especial levando a uma maior inserção de dispositivos de tecnologia, seja equipamentos ou softwares, no processo de comunicação dos ritos celebrados pela fé católica nesta comunidade. Para além de um suporte onde se transmite a fé católica, trata-se claramente de um ambiente de produção conteúdo novo, que preencha lacunas causadas pelo distanciamento provocado pela pandemia que atinge $o$ mundo e, potencialmente, tem condições de impactar profundamente os modos de prática dos ritos e da confissão católica nesta comunidade.

\section{Considerações finais}

De modo geral é possível perceber o aumento repentino, e crescente adesão, ao uso da internet, e dos recursos por ela proporcionados, nas atividades de comunicação da Paróquia em Presidente Médici. Praticamente todas as mudanças passam por essa estratégia que em primeiro momento era secundária nas ações comunicacionais escolhidas pela comunidade católica de Presidente Médici. Não se pode afirmar que isso é resultado exclusivo do isolamento social de fato, ou uma escolha por outras questões. No entanto, trata-se certamente de elemento importante para a compreensão deste cenário. $O$ fato é que cada vez mais a Paróquia São João Batista tem encontrado na internet uma solução para tentar minimizar os efeitos do isolamento social.

Seja através da transmissão da missa, produção de conteúdos formativos, transmissão de momentos de oração, a catequese via videoconferência ou até mesmo lives com música e bate papo, a internet se transformou em um 


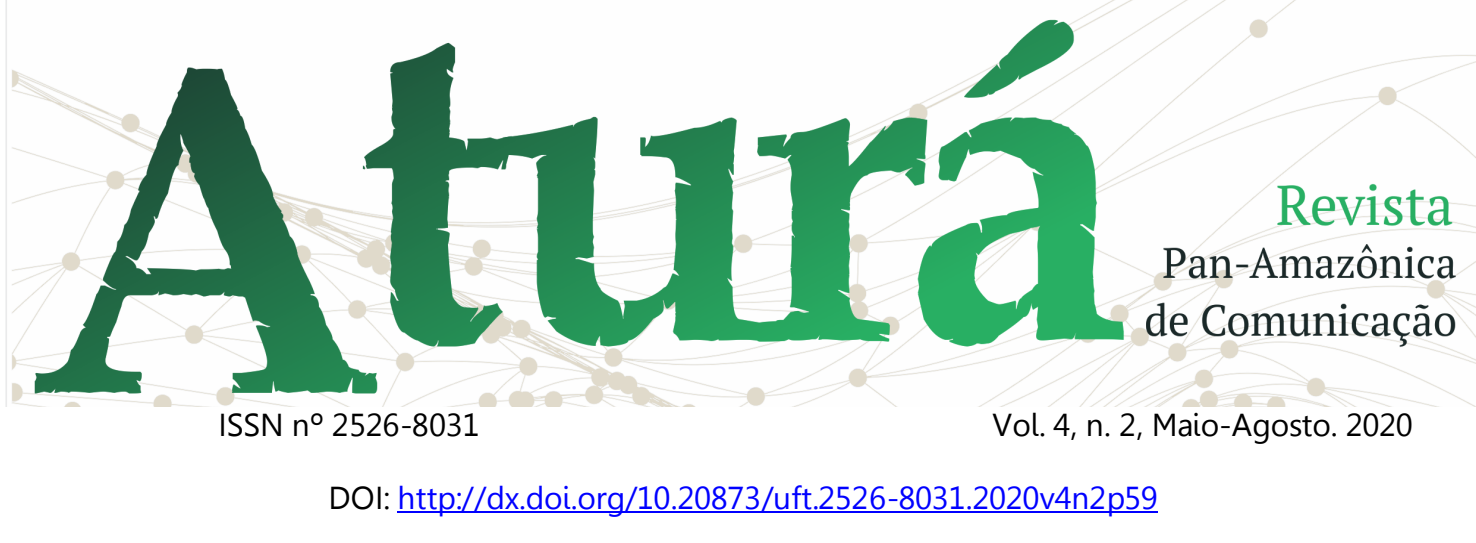

ambiente por onde circula a maioria das ações promovidas pela paróquia. Os programas de rádio ainda possuem sua importância, alcançando aqueles que estão mais distantes e não têm condições para acessar à internet e, assim, ficam à margem deste processo de transformação das ações de comunicação paroquial, ou têm dificuldades de lidar com artefatos e softwares, o que é especialmente presente entre fiéis idosos.

A partir deste cenário que está em transformação, tanto na Igreja Católica de modo geral, como na paróquia do interior de Rondônia aqui foco de atenção, é pertinente a apresentação de algumas questões que não foram, e nem pretendiam ser, respondidas neste artigo. De fato, a pandemia do novo Coronavírus foi o motivador principal para que as estratégias midiáticas de Presidente Médici, e de forma específica o uso da internet, pudesse sofrer alterações em um período muito curto de tempo? Mesmo sendo comparado com as estratégias utilizadas em 2017, e apresentadas em pesquisa anterior (CUNHA, 2017), a partir da observação das mídias sociais, principalmente Facebook e Youtube é possível perceber que as atividades nessas redes começaram no fim de março e seguem alterando os modos de interação entre os católicos de Presidente Médici.

Também é importante se atentar para as alterações nos usos das mídias, como refletiram na comunidade católica de Presidente Médici, e se de fato as ações realizadas promoveram o sentimento de pertença nos fiéis católicos que neste momento se encontram afastados da convivência social. Outra questão que pode ser posta para discussão diz respeito ao uso das estratégias midiáticas: as estratégias que são acionadas durante a pandemia conseguem tornar possível viver a comum e unidade a fé católica?

Por fim, há uma questão que provavelmente só poderá ser devidamente respondida com o passar do tempo, pois diz respeito à possibilidade de que as estratégias acionadas neste tempo possam se manter após a 


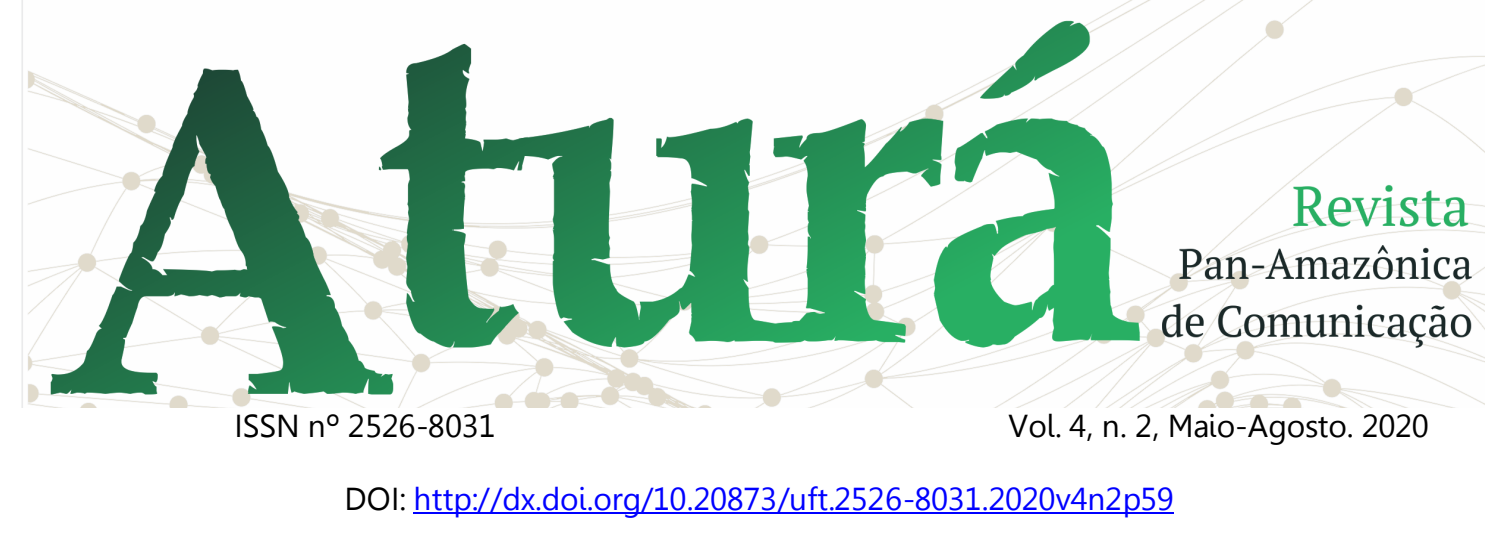

normalização desta situação no mundo. De fato, elas irão alterar a forma como a paróquia São João Batista de Presidente Médici utiliza as estratégias midiáticas ou as estratégias acionadas neste tempo foram uma resposta rápida às necessidades e após este tempo tudo voltará a ser como era anteriormente?

Para esta pergunta um pouco mais de tempo e observação são necessários, e neste caminho que seguimos atentos em busca de resposta. Neste momento o que fazemos é observar e organizar as questões fundamentais para compreender um fenômeno que é global, mas que por certo tem dimensões e comportamentos particulares dados os contextos em que se manifesta.

\section{Referências}

ALOISIO, Daniel. 'Igrejas eletrônicas': saiba como católicos vão viver a Páscoa na quarentena. Jornal Correio. Salvador/BA. 8 de março de 2020. Disponível em: <https://www.correio24horas.com.br/noti cia/nid/igrejas-eletronicas-saiba-comocatolicos-vao-viver-a-pascoa-naquarentena/>. Acesso em 18/06/2020.
AQUINO, Felipe. Os 5 mandamentos da Igreja. In: Católico Orante. Disponível em: $<$ http://www.catolicoorante.com.br/5man damentos.html> / Acesso em: 19/06/2020.

ASSOCIAÇÃO EVANGELIZAR. In: Associação Evangelizar é preciso. s/d. Disponível em: $<$ https://www.padrereginaldomanzotti.or g.br/associacao/> acesso em 22/06/2020.

CENSO DEMOGRÁFICO 2010. Sinopse: Presidente Médici/RO. Disponível em: <https://cidades.ibge.gov.br/brasil/ro/pre sidentemedici/pesquisa/23/27652?detalh es $=$ tru e $>$. Acesso em: 25/11/2017.

CORONAVÍRUS FEZ NASCER primeiro canal católico na Romênia. In: Vatican News. 16 de Junho 2020. Disponível em: $<$ https://www.vaticannews.va/pt/igreja/ne ws/2020-06/romen ia-primeiro-canal-tvcatolico.html> / Acesso em 16/06/2020.

CRESCE AUDIÊNCIA de emissoras de rádio e Tv de inspiração católica no país por causa do coronavírus. In: CNBB. 7 de março de 2020. Disponível em: $<$ https://www.cnbb.org.br/cresceaudiencia-de-emissoras-de-radio-e-tvde-inspiracao-catolica-no-pais-porcausa-do-coronavirus/ $>$ Acesso em 18/06/2020.

CUNHA, Cadidja Medeiros Barros. Estratégias midiáticas na paróquia de Presidente Médici. 2016. 54 f. Trabalho de Conclusão de Curso (Graduação) - 


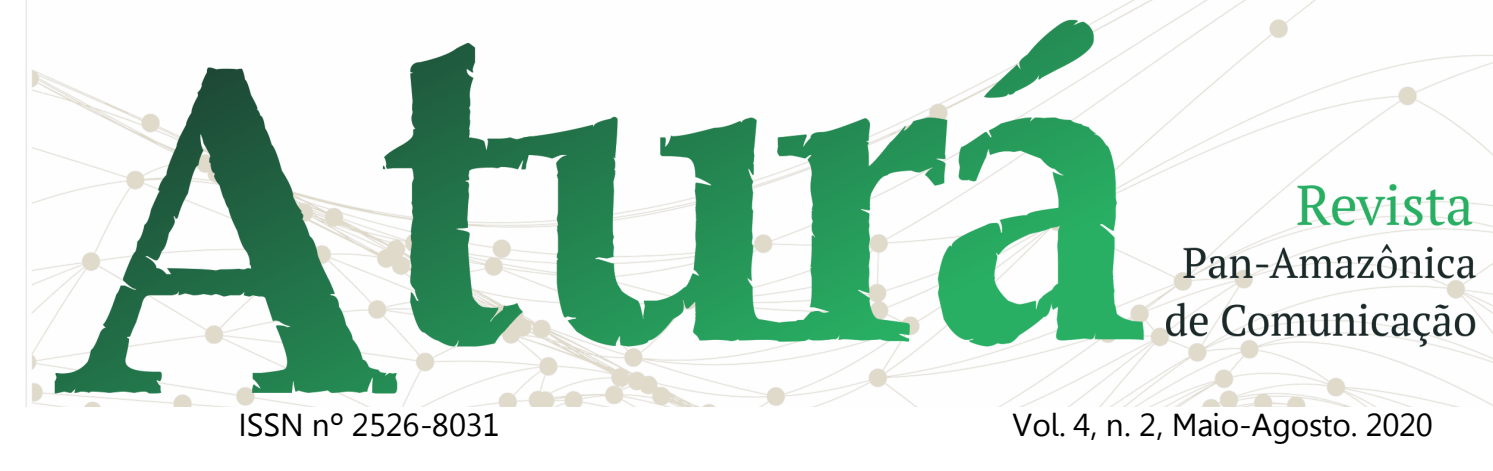

DOI: http://dx.doi.org/10.20873/uft.2526-8031.2020v4n2p59

Universidade Federal de Rondônia, Unir, Vilhena 2016.

GREGOLIN, Marina Tavares. O que é a Legião de Maria. In: Legião de Maria s/d. Disponível em: <https://www.legiaodemaria.org.br/oque-e-a-legiao-de-maria $>/$ Acesso em 19/06/2020.

JOÃO PAULO II, Instrução Pastoral Aetatis Novae. 1992. Documento disponível em formato digital. Disponível em <http://www.vatican.va/roman_curia/pont ifical_councils/pccs/documen ts/rc_pc_pccs_doc_22021992_aetatis_po.ht $\mathrm{ml}>$. Acesso em 22/10/2017, 14:35:27.

MARKMAN, Luna. Padre reza missa com fotos dos fiéis nos bancos da igreja: 'dá conforto e alegria'. Globo News. Recife/ PE. 30 de março de 2020. Disponível em: $<$ https://g1.globo.com/pe/pernambuco/n oticia/2020/03/30/padre-reza-missacom-fotos-dos-fieis-nos-bancos-daigreja-e-esquisito-ficar-olhando-para-acamera.ghtml/>Acesso em: 18/06/2020.

MARTINO, Luís Mauro Sá. Mídia, religião e sociedade: Das palavras às redes digitais. $1^{\circ}$ ed. São Paulo: Paulus, 2016.

NOTA OFICIAL da diocese de Ji-Paraná sobre a covid-19 (coronavírus). In: Diocese De Ji-Paraná. 18 de março de $2020 . \quad$ Disponível em: <http://www.diocesedejiparana .org.br/noticias-det.php?cod=4018 / Acesso em: 19/06/2020.
PADRE FAZ transmissão de benção online e vira meme com filtros divertidos "acionei sem querer". In: G1 31 de março 2020. Disponível em: https://g1.glob o.com/pop-

arte/noticia/2020/03/31/padre-faztransmissao-de-bencao-on-line-e-virameme-com-filtros-divertidos-acioneisem-querer.ghtml./ Acesso em: 19/06/2020.

PAPA FRANCISCO CONCEDE indulgência plenária para a oração de 27 de março. In: ACN. 27 de março de 2020. Disponível em: $\quad$ https://www.acn.org.br/papafrancisco-concede-indulgencia-plenariapara-a-oracao-de-27-de-marco/>Acesso em: 18/06/2020.

PAPA FRANCISCO REALIZA benção sozinho no Vaticano, por conta do coronavírus, e imagens chocam internautas. In: TV Jornal. 27 de março $2020 . \quad$ Disponível em: $<$ https://tvjornal.ne10.uol.com.br/noticias /2020/03/27/papa-francisco-realizabencao-sozinho-no-vaticano-por-contado-coronavirus-e-imagens-chocaminternautas-186082/> Acesso em: 19/06/2020.

PASCOM: TRABALHO de comunicação na Igreja é estar a serviço da evangelização. In: CNBB. 11 de maio de 2018. Dispinível em: < https://www.cnbb.org.br/pascomtrabalho-de-comunicacao-na-igreja-eestar-a-servico-da-evangelizacao/> / Acesso em 19/06/2020. 


\section{A \\ ISSN n² 2526-8031
 \\ á \\ Vol. 4, n. 2, Maio-Agosto. 2020 \\ DOI: http://dx.doi.org/10.20873/uft.2526-8031.2020v4n2p59}

PAULO VI, Instrução pastoral Comunio et Progressio. 1971. Disponível em <http://www.vatican.va/roman_curia/pont ifical_councils/pccs/documents/rc_pc_pcc s_doc_23051971_communio_po.html $>$. Acesso em 25/11/2017 às 16:25:30

PAULO VI. Decreto Inter Mírifica. 1966. Documento em formato digital. Disponivel em: $<$ http://www.vatican.va/archive/hist_coun cils/ii_vatican_council/documents/vatii_decree_19>. Acesso em Acesso em 22/10/2017, 14:45:35.

PIO XI. Carta encíclica Vigilanti Cura. 1936. documento em formato digital. Disponível em: $<$ http://w2.vatican.va/content/piusxi/pt/encyclicals/documents/hf_pxi_enc_29061936_vigilan tiura.html >.Acesso em 09/10/2017, 10:14:22.

PIO XII, Carta encíclica Miranda Prorsus. 1957. Documento em formato digital. Disponível em <http://w2.vatican.va/content/paul$\mathrm{vi} / \mathrm{pt} /$ apost_exhortations/documents/hf_p -vi_enc_08091957_ mirandaprorsus.html>. Acesso em: 09/10/2017. PIRES, Edna Perez. CORAZZA FSP, Ir. Helena. Caminhos E Perspectivas Signis Brasil - 2010 - 2016. s/d. Disponível em:<https://signis.org.br/2017/use rfiles/ckeditor/Signis\%20Brasil/ Relatório_final_Signis_brasil.pdf > / Acesso em 19/06/2020.
PUNTEL, Joana T. A igreja a caminho na comunicação. Porto Alegre: Revista Teocomunicações, 2011. Disponível em $<$ revistaseletronicas. pucrs.br/ojs/index.ph $\mathrm{p} /$ teo/article/v iewFile/9755/6685>. Acesso em 05/06/2017, 10:04:55.

QUEM SOMOS. In: CNBB. s/d. Disponível em: $\quad<$ https://www.cnbb.org.br/quemsomos/> / Acesso em 19/06/2020.

QUÉNIA. IGREJA lança canal de TV para transmitir esperança em tempo de Covid19. In: Vatican News. 04 abril 2020. Disponível em: $<$ https://www.vaticannews.va/pt/africa Lnews/2 020-04/quenia-igreja-lancacanal-de-levisao-para-transmitiresperanca.html> Acesso em: 19/06/2020. 